\title{
Melalui Metode Belajar Aktif Model Gabungan Ceramah dan Kerja Kelompok dapat Meningkatkan Kinerja Guru Mengajar di MTsN 2 Mataram Pada Semester Genap Tahun Pelajaran 2017/2018
}

\author{
Siti Rubianingsih ${ }^{1}$ \\ ${ }^{1}$ Kementerian Agama Kota Mataram.
}

*Corresponding Author: Siti Ruianingsih,

Kementerian Agama

Kota Mataram,

Indonesia;

Email:

n1ng51g@yahoo.co.id

\begin{abstract}
Abstrak: Penelitian ini bertujuan untuk mengetahui tingkat penguasaan yang telah dipelajari di MTsN 2 Mataram dan mengetahui pengaruh positif setelah metode belajar aktif model gabungan ceramah dan kerja kelompok diterapkan oleh guru di MTsN 2 Mataram. Penelitian ini dilaksanakan dalam dua siklus masing-masing terdiri dari satu kali pertemuan. Kesimpulannya, yaitu: 1) Pembelajaran dengan metode belajar aktif model gabungan ceramah dan kerja kelompok memiliki dampak positif dalam meningkatkan kinerja guru yang ditandai dengan peningkatan rata-rata ketuntasan belajar siswa dalam setiap siklus, yaitu siklus I (62,00\%), dan siklus II (97,00\%). 2) Penerapan metode belajar aktif model gabungan ceramah dan kerja kelompok mempunyai pengaruh positif, yaitu dapat meningkatkan motivasi belajar siswa yang ditunjukan dengan rata-rata jawaban siswa yang menyatakan bahwa siswa tertarik dan berminat dengan metode belajar aktif model gabungan ceramah dan kerja kelompok pada materi pelajaran sehingga mereka menjadi termotivasi untuk belajar.
\end{abstract}

Kata Kunci: Belajar aktif, Ceramah, Kerja Kelompok, dan Kinerja Guru

\section{Pendahuluan}

Proses pembelajaran merupakan suatu proses yang mengandung serangkaian pelaksanaan oleh guru dan siswa atas dasar hubungan timbal-balik yang berlangsung dalam situasi edukatif untuk mencapai tujuan tertentu. Interaksi atau hubungan timbal balik antara guru dan siswa ini merupakan syarat utama bagi berlangsungnya proses pembelajaran. Pada kenyataan yang terlihat di madrasah-madrasah/sekolah-sekolah, seringkali guru terlalu aktif di dalam proses pembelajaran, sementara siswa dibuat pasif, sehingga interaksi antara guru dengan siswa dalam proses pembelajaran tidak efektif. Jika proses pembelajaran lebih didominasi oleh guru, maka efektifitas pembelajaran agak sulit dapat dicapai.

Slameto (2003) menyatakan "belajar merupakan suatu proses usaha yang dilakukan seseorang untuk memperoleh suatu perubahan tingkah laku yang baru secara keseluruhan, sebagai hasil pengalamannya sendiri dalam interaksi dengan lingkungannya". Untuk mendapatkan sesuatu seseorang harus melakukan usaha agar apa yang di inginkan dapat tercapai. Usaha tersebut dapat berupa kerja mandiri maupun kelompok dalam suatu interaksi

Untuk menciptakan kondisi pembelajaran yang efektif, guru dituntut agar mampu mengelola proses pembelajaran yang memberikan rangsangan kepada siswa sehingga siswa mau dan mampu belajar. Untuk bisa belajar efektif, setiap orang perlu mengetahui apa arti belajar sesungguhnya. Belajar adalah sebuah tindakan aktif untuk memahami dan mengalami sesuatu. Belajar merupakan akibat adanya interaksi antara stimulus dan respon. Jadi, proses belajar terjadi jika anak merespon stimulus (rangsangan) yang diberikan guru, selain itu untuk meraih pembelajaran yang efektif peserta didik juga dapat dibimbing oleh guru dari pengetahuan sebelumnya yang mereka miliki yang tersimpan dalam ingatan dan pemikiran mereka (kognitif) dengan menggunakan teori dan metode pembelajaran dengan tepat. Jika hal itu belum terjadi maka proses pembelajaran tidak akan berjalan dengan efektif dan optimal tanpa 
menyiapkan sejumlah perangkat pembelajaran dan metode yang tepat.

Metode adalah cara yang fungsinya sebagai alat untuk mencapai tujuan. Makin baik metode itu, makin efektif pula pencapaian tujuan. Dengan demikian tujuan merupakan faktor utama dalam menetapkan baik tidaknya penggunaan suatu metode. Dalam hal metode mengajar, selain faktor tujuan, murid, situasi, fasilitas dan faktor guru turut menentukan efektif tidaknya penggunaan suatu metode. Karenanya metode mengajar itu banyak sekali dan sulit menggolong-golongkannya. Lebih sulit lagi menetapkan metode mana yang memiliki efektifitas paling tinggi. Sebab metode yang "kurang baik" di tangan seorang guru dapat menjadi metode yang "baik sekali" di tangan guru yang lain dan metode yang baik akan gagal di tangan guru yang tidak menguasai teknik pelaksanaannya. Namun demikian, ada sifat-sifat umum yang terdapat pada metode yang satu tidak terdapat pada metode yang lain. Dengan mencari ciri-ciri umum itu, menjadi mungkinlah untuk mengenali berbagai macam metode yang lazim dan praktis untuk dilaksanakan dalam proses belajar mengajar.

Belajar mengajar merupakan kegiatan yang kompleks. Mengingat kegiatan belajar mengajar merupakan kegiatan yang kompleks, maka tidak mungkin menunjukkan dan menyimpulkan bahwa suatu metode belajar mengajar tertentu lebih unggul dari pada metode belajar mengajar yang lainnya dalam usaha mencapai semua pelajaran, dalam situasi dan kondisi, dan untuk selamanya. Oleh karena itu, sudah sepantasnya seorang guru memahami dan mengaplikasikan berbagai macam metode dalam proses pembelajaran di kelas.

Penggunaan metode pembelajaran yang baik dalam proses pembelajaran, tentu akan mampu menigkatkan pemahaman siswa dalam menerima pembelajaran di kelas. Suatu proses pembelajaran agar dapat berhasil dengan baik harus memerlukan usaha yang sungguh-sungguh dari semua pihak, baik dari pihak siswa, guru, orang tua siswa, lingkungan sekolah, maupun pemerintah. Guru diharapkan dapat memilih metode yang baik dan tepat sehingga proses belajar mengajar dapat berjalan dengan efektif dan berhasil dengan baik. Akan tetapi masih ada sebagian guru sekolah dasar yang mengajar secara klasik yang hanya dengan menggunakan satu metode saja, di antaranya metode ceramah yang termasuk dalam klasifikasi metode konvensional.

Bagaimanakah caranya agar siswa tidak melupakan materi pelajaran yang telah diterimanya agar siswa nantinya siap menghadapi ujian kenaikan kelas yang siap atau tidak siap harus mereka hadapi. Bagaimanakah membuat suatu materi ajar agar agar tidak terlupakan oleh anak didik. Dalam hal ini guru harus mencari metode untuk mengingatkan segala memori di benak siswa yang telah mereka terima. Guru harus bisa membangkitkan kembali memori itu. Salah satu metode pengajaran yang bisa membuat anak bisa dan harus mengingat kembali materi pelajaran yang telah mereka terima adalah cara belajar aktif model pembelajaran gabungan model ceramah dan kerja kelompok. Belajar memerlukan keterlibatan mental dan kerja siswa sendiri. Penjelasan dan pemeragaan semata tidak akan membuahkan Kinerja Guru yang hanyalah kegiatan belajar aktif.

Rosida (2011) menyatakan bahwa active learning (belajar aktif) pada dasarnya berusaha untuk memperkuat dan memperlancar stimulus dan respon anak didik dalam pembelajaran, sehingga proses pembelajaran menjadi hal yang menyenangkan, tidak menjadi hal yang membosankan bagi mereka. Untuk bisa belajar efektif, setiap orang perlu mengetahui apa arti belajar sesungguhnya.

Agar belajar manjadi aktif, siswa harus mengerjakan banyak sekali tugas. Mereka harus menggunakan otak, mengkaji gagasan, memecahkan masalah, dan menerapkan apa yang mereka pelajari. Belajar aktif harus gesit, menyenangkan, bersemangat dan penuh gairah. Siswa bahkan sering meninggalkan tempat duduk mereka, bergerak leluasa dan berfikir keras (moving about dan thinking aloud).

Berpijak dari latar belakang permasalahan tersebut di atas, maka dalam penelitian tindakan sekolah wilayah (PTSW) ini penulis mengambil judul: "Melalui Metode Belajar Aktif Model Gabungan Ceramah Dan Kerja Kelompok Dapat Meningkatkan Kinerja Guru Mengajar Guru di MTsN 2 Mataram Pada Semester Genap Tahun Pelajaran 2017/2018.

\section{Metode}

Penelitian ini berfokus pada masalah tindakan guru dengan menerapkan konsepsi cara 
belajar aktif model pembelajaran gabungan model ceramah dan kerja kelompok. Penelitian ini merupakan penelitian kelas (classroom reaserch) yang berkolaborasi dengan tindakan kepengawasan, dimana peneliti hanya melakukan observasi di kelas dan guru melakukan tindakan kelas, penelitian ini biasa disebut penelitian tindakan kolabaratif.

Penelitian kelas dan penelitian tindakan kepengawasan mampu menawarkan pendekatan dan prosedur baru yang lebih menjanjikan dampak langsung dalam bentuk perbaikan dan peningkatan profesionalisme guru dalam mengelola proses belajar di kelas atau implementasi berbagai program di sekolah dengan mengkaji berbagai indikator keberhasilan proses dan hasil pembelajaran yang terjadi pada siswa. Subyek penelitian ini adalah beberapa guru yang sedang dan pernah mengajar di MTsN 2 Mataram.

Sesuai dengan jenis penelitian yang dipilih, yaitu penelitian tindakan, maka penelitian ini menggunakan model penelitian tindakan dari Kemmis dan Taggart (dalam Sugiarti, 1997: 6), yaitu berbentuk spiral dari sklus yang satu ke siklus yang berikutnya. Setiap siklus meliputi planning (rencana), action (tindakan), observation (pengamatan), dan reflection (refleksi). Langkah pada siklus berikutnya adalah perncanaan yang sudah direvisi, tindakan, pengamatan, dan refleksi. Sebelum masuk pada siklus 1 dilakukan tindakan pendahuluan yang berupa identifikasi permasalahan. Siklus spiral dari tahap-tahap penelitian tindakan kelas dapat dilihat pada gambar berikut.

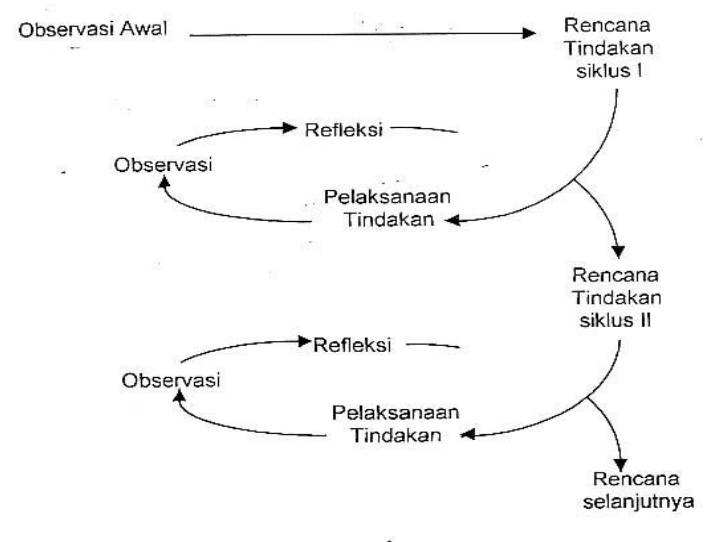

Gambar 1. Alur Penelitian Tindakan

Instrumen yang digunakan dalam penelitian adalah silabus kepengawasan, rencana pembelajaran, form LKS, dan tes formatif. Data- data yang diperlukan dalam penelitian ini diperoleh melalui observasi pengolahan metode pembelajaran aktif model gabungan ceramah dan kerja kelompok pada materi pelajaran, dan soal ujian.

Pada penelitian ini menggunakan teknik analisis deskriptif kualitatif, yaitu suatu metode penelitian yang bersifat menggambarkan kenyataan atau fakta sesuai dengan data yang diperoleh dengan tujuan untuk mengetahui kinerja guru yang dicapai siswa juga untuk memperoleh respon siswa terhadap kegiatan pembelajaran serta aktivitas siswa selama proses pembelajaran. Untuk mengalisis tingkat keberhasilan atau persentase keberhasilan siswa setelah proses belajar mengajar setiap putarannya dilakukan dengan cara memberikan evaluasi berupa soal tes tertulis pada setiap akhir putaran.

Analisis ini dihitung dengan menggunakan statistik sederhana penjumlahan nilai yang diperoleh siswa, yang selanjutnya dibagi dengan jumlah siswa yang ada di kelas tersebut sehingga diperoleh rata-rata soal ujian dapat dirumuskan:

$$
\bar{X}=\frac{\sum X}{\sum N}
$$

Dengan:

$$
\begin{aligned}
\bar{X} & =\text { Nilai rata-rata } \\
\Sigma \mathrm{X} & =\text { Jumlah semua nilai siswa } \\
\Sigma \mathrm{N} & =\text { Jumlah siswa (Arikunto, 2010). } \\
& \text { Analisis ketuntasan belajar dilakukan }
\end{aligned}
$$
secara perorangan dan secara klasikal. Seorang siswa telah tuntas belajar bila telah mencapai skor $65 \%$ atau nilai 65 , dan kelas disebut tuntas belajar bila di kelas tersebut terdapat $85 \%$ yang telah mencapai daya serap lebih dari atau sama dengan $65 \%$. Untuk menghitung persentase ketuntasan belajar digunakan rumus sebagai berikut:

$$
P=\frac{\sum \text { Siswa.yang.tuntas.belajar }}{\sum \text { Siswa }} \times 100 \%
$$

\section{Hasil dan Pembahasan}

\section{Siklus I}

Tahap Planning

Pada planning peneliti mempersiapkan perangkat pembelajaran yang terdiri dari rencana pembelajaran 1, soal ujian 1 dan alat-alat pengajaran yang mendukung. 
Pada tahap action, Pelaksanaan kegiatan belajar mengajar untuk siklus I dilaksanakan pada bulan Februari di Kelas VIII MTsN 2 Mataram dengan jumlah siswa 30 siswa. Proses pembelajaran yang diawasi oleh peneliti adalah pembelajaran pada mata pelajaran Matematika, Bahasa Indonesia, Iilmu Pengetahuan Alam, Ilmu Pengetahuan Sosial, dan Pendidikan Agama. Dalam hal ini peneliti hanya mengawasi guru-guru yang mengajar pada saat jam mengajar. Adapun proses belajar mengajar mengacu pada rencana pembelajaran yang telah dipersiapkan. Pengamatan (observasi) dilaksanakan bersamaan dengan pelaksaaan belajar mengajar.

Hasil penelitian menunjukkan bahwa dengan menerapkan metode belajar aktif model gabungan ceramah dan kerja kelompok pada Kelas VIII MTsN 2 Mataram, nilai rata-rata siswa sebesar 67 untuk mata pelajaran matematika, 68,67 pada mata pelajaran Bahasa Indonesia, 61,67 pada mata pelajaran IPA, 65,67 pada mata peajaran IPS, dan 70 pada mata pelajaran PAI. Ketuntasan belajar diperoleh sebesar $63,00 \%$ untuk mata pelajaran matematika, $70,00 \%$ pada mata pelajaran Bahasa Indonesia, 47,00\% pada mata pelajaran IPA, $57,00 \%$ pada mata peajaran IPS, dan $73,00 \%$ pada mata pelajaran PAI.

Hasil tersebut menunjukkan bahwa pada siklus pertama secara klasikal siswa belum tuntas belajar, karena siswa yang memperoleh nilai $\geq 65$ rata-rata hanya sebesar $62 \%$ lebih kecil dari persentase ketuntasan yang dikehendaki yaitu sebesar $85 \%$. Hal ini disebabkan karena siswa banyak yang lupa dengan materi pelajaran yang telah diajarkan selama hampir satu semester ini.

\section{Siklus II}

Pada tahap planning peneliti mempersiapkan perangkat pembelajaran yang terdiri dari rencana pembelajaran 2, soal ujian II dan alat-alat pengajaran yang mendukung.

Pelaksanaan kegiatan belajar mengajar untuk siklus II dilaksanakan pada bulan Maret di Kelas VIII MTsN 2 Mataram dengan jumlah siswa 30 siswa. Proses pembelajaran yang diawasi oleh peneliti adalah pembelajaran pada mata pelajaran Matematika, Bahasa Indonesia, Iilmu Pengetahuan Alam, Ilmu Pengetahuan Sosial, dan Pendidikan Agama. Dalam hal ini peneliti hanya mengawasi guru-guru yang mengajar pada saat jam mengajar. Adapun proses belajar mengajar mengacu pada rencana pembelajaran yang telah dipersiapkan.
Pengamatan (observasi) dilaksanakan bersamaan dengan pelaksaaan belajar mengajar.

Dari hasil penelitian diperoleh bahwa dengan menerapkan metode belajar aktif model gabungan ceramah dan kerja kelompok pada Kelas VIII MTsN 2 Mataram, nilai rata-rata siswa sebesar 78,50 untuk mata pelajaran matematika, 81,16 pada mata pelajaran Bahasa Indonesia, 77,50 pada mata pelajaran IPA, 80,33 pada mata peajaran IPS, dan 79,83 pada mata pelajaran PAI. Ketuntasan belajar diperoleh sebesar 93,00\% untuk mata pelajaran matematika, 97,00\% pada mata pelajaran Bahasa Indonesia, 97,00\% pada mata pelajaran IPA, $100,00 \%$ pada mata peajaran IPS, dan $100,00 \%$ pada mata pelajaran PAI. Sehingga rata-rata ketuntasan belajar siswa Kelas VIII MTsN 2 Mataram sebesar 97,00\%.

Hasil tersebut menunjukkan bahwa pada siklus pertama secara klasikal siswa belum tuntas belajar, karena siswa yang memperoleh nilai $\geq 65$ rata-rata hanya sebesar $97 \%$ lebih besar dari persentase ketuntasan yang dikehendaki yaitu sebesar $85 \%$. Hal ini ini menunjukkan bahwa metode belajar aktif model gabungan ceramah dan kerja kelompok dapat meningkatkan prestasi belajar siswa sehingga berdampak pada peningkatan kinerja guru mengajar di MTsN 2 Mataram Pada Semester Genap Tahun Pelajaran 2017/2018.

Adanya peningkatan prestasi siswa ini karena siswa-siswa telah mulai mengulang pelajaran yang sudah diterimanya selama ini sehingga para siswa sebagian sudah mengingat materi yang telah diajarkan oleh guru.

Melalui hasil peneilitian ini menunjukkan bahwa metode belajar aktif model gabungan ceramah dan kerja kelompok pada materi pelajaran memiliki dampak positif dalam meningkatkan kinerja guru siswa. Hal ini dapat dilihat dari semakin mantapnya pemahaman siswa terhadap materi yang disampaikan guru untuk menghadapi ujian kenaikan kelas (rata-rata ketuntasan belajar meningkat dari sklus I, dan II) yaitu masing-masing $62,00 \%$, dan 97,00\%. Pada siklus II ketuntasan belajar siswa secara klasikal telah tercapai.

Berdasarkan analisis data, diperoleh aktivitas siswa dalam proses metode belajar aktif model gabungan ceramah dan kerja kelompok pada materi pelajaran dalam setiap siklus mengalami peningkatan. Hal ini berdampak positif terhadap Kinerja Guru siswa yaitu dapat ditunjukkan dengan 
meningkatnya nilai rata-rata siswa pada setiap siklus yang terus mengalami peningkatan

Berdasarkan analisis data, diperoleh aktivitas siswa dalam proses pembelajaran dengan metode belajar aktif model Gabungan Ceramah dan Kerja Kelompok pada materi pelajaran yang paling dominan adalah bekerja dengan menggunakan alat/media, mendengarkan/ memperhatikan penjelasan guru, dan diskusi antar siswa/antara siswa dengan guru. Jadi, dapat dikatakan bahwa aktivitas siswa dapat dikategorikan aktif.

Sedangkan untuk aktivitas guru selama pembelajaran telah melaksanakan langkah-langkah metode belajar aktif model Gabungan ceramah dan kerja kelompok pada materi pelajaran dengan baik. $\mathrm{Hal}$ ini terlihat dari aktivitas guru yang muncul di antaranya aktivitas membimbing dan mengamati siswa dalam mengerjakan kegiatan pembelajaran, menjelaskan materi yang sulit, memberi umpan balik dimana prosentase untuk aktivitas di atas cukup besar.

\section{Kesimpulan}

Hasil kegiatan pembelajaran yang telah dilakukan selama tiga siklus, dan berdasarkan seluruh pembahasan serta analisis yang telah dilakukan dapat disimpulkan sebagai berikut: 1) Pembelajaran dengan metode belajar aktif model gabungan ceramah dan kerja kelompok memiliki dampak positif dalam meningkatkan kinerja guru yang ditandai dengan peningkatan rata-rata ketuntasan belajar siswa dalam setiap siklus, yaitu siklus I $(62,00 \%)$, dan siklus II $(97,00 \%)$. 2) Penerapan metode belajar aktif model gabungan ceramah dan kerja kelompok mempunyai pengaruh positif, yaitu dapat meningkatkan motivasi belajar siswa yang ditunjukan dengan rata-rata jawaban siswa yang menyatakan bahwa siswa tertarik dan berminat dengan metode belajar aktif model gabungan ceramah dan kerja kelompok pada materi pelajaran sehingga mereka menjadi termotivasi untuk belajar.

\section{Saran}

Berdasarkan hasil penelitian ini, disarankan bahwa dalam rangka meningkatkan kinerja guru dan siswa, guru hendaknya lebih sering melatih siswa dengan berbagi metode, walaupun dalam taraf yang sederhana, dimana siswa nantinya dapat menemukan pengetahuan baru, memperoleh konsep dan keterampilan, sehingga siswa berhasil atau mampu memecahkan masalah-masalah yang dihadapinya. Selain itu, perlu adanya penelitian yang lebih lanjut, karena penelitian ini hanya dilakukan di MTsN 2 Mataram sebagai madrasah binaan.

Untuk melaksanakan metode belajar aktif model gabungan ceramah dan kerja kelompok memerlukan persiapan yang cukup matang, sehingga guru harus mampu menentukan atau memilih topik yang benar-benar bisa diterapkan

\section{Daftar Pustaka}

Arikunto, S. 2010. Prosedur Penelitian Suatu Pendekatan Praktik. Jakarta: PT Bumi Aksara.

Rosida, Postalina \& Titin Suprihatin. 2011. Pengaruh pembelajaran aktif dalam meningkatkan prestasi belajar Fisika pada siswa kelas 2 SMU. Proyeksi, Vol. 6 (2) 2011, 89-102.

Slameto. 2013. Belajar dan Faktor-Faktor yang Mempengaruhinya. Jakarta: PTRineka Cipta.

Sugiarti, Titik. 1997. Motivasi Belajar. Jakarta: Cerdas Pustaka 